\title{
A Soldagem e Seus Extremos
}

\author{
Alexandre Queiroz Bracarense ${ }^{1}$ \\ 1 Universidade Federal de Minas Gerais - IFMG, Laboratório de Robótica, Soldagem e Simulação - LRSS, Belo Horizonte, MG, \\ Brasil.
}

E-mail: bracarense@ufmg.br (AQB)
Este é um artigo publicado em acesso aberto (Open Access) sob a licença Creative Commons Attribution Non-Commercial, que permite uso, distribuição e reprodução em qualquer meio, sem restriçōes desde que sem fins comerciais e que 0 trabalho original seja corretamente citado.
Fiquei muito lisonjeado quando fui convidado para fazer o Editorial deste número. Fiquei por que existem três assuntos os quais tem me deixado muito e a cada dia mais empolgado com a soldagem. O primeiro é com relação à participação das mulheres na área. Neste sentido, me lembrei de um artigo que o nosso querido e saudoso amigo Mário Cenni escreveu há muito tempo, chamado "O Homem Soldador" [Infelizmente não achei a referência]. Na ocasião, o Mário deixou clara a importância da profissão e como era ou é dura a vida de um soldador. No artigo em questão não foi nem mencionado a possibilidade do tal soldador ser uma soldadora. Pois é, hoje é fácil ver "soldadoras". Elas estão em vários postos. Trabalham tão bem, se não, até melhor que os soldadores. Recentemente, uma empresa "inovadora", fabricante de tratores aqui de Minas Gerais solicitou e contratou várias soldadoras. Eu indiquei duas do CIPMOI - Curso Intensivo de Preparação de Mão de Obra Industrial - aqui da UFMG [1]. Quem leu o Welding Journal do mês de julho [2,3], viu que nos Estados Unidos, a presença das mulheres está aumentando e que isto tem sido um diferencial na participação delas na renda familiar. Não é legal isto? Não é importante? E a participação não fica somente nas bases, elas estão na formação. Já não podemos contar nos dedos o número de "doutoras" com título em soldagem no Brasil. Só aqui na UFMG já se formaram 6 doutoras em soldagem. São tantas e outras tantas em várias outras universidades. Elas estão nos Institutos Federais, nos Cefet's, nas PUC's e nas Federais. Estão disseminando a área. Estão fazendo com que outras e outras fiquem a cada dia mais e mais apaixonadas com soldagem. É como uma aluna minha escreveu recentemente no Instagram sobre o TCC dela: "soldagem sua linda". Precisamos agora vê-las publicando mais, principalmente na Soldagem \& Inspeção.

Outro assunto que gostaria de ressaltar é o da robotização da soldagem. Quando fundei meu laboratório em 1995, usei um projeto que foi financiado pela FINEP no edital RECOPE. O título do projeto é "Soldagem Robotizada". A ideia era exatamente estudar a soldagem para aplicar a robotização. O contrário do que muitos pensavam, inclusive de onde eu havia tirado a ideia, ou seja, nos Estados Unidos. Na época pensavam em colocar o robô no lugar do soldador. Esta era uma ideia completamente anti-humana, ou seja, criava-se muito conflito ideológico do uso do robô. O que eu propus era exatamente o contrário. A proposta era ensinar soldagem ao robô e quem deveria fazer isto deveria ser o próprio soldador. Nesta, é claro, somente ficariam os melhores soldadores. Convenhamos ninguém quer um soldador ruim. Pois bem, a proposta era como ensinar um robô a manipular uma espada. Não pode ser qualquer um, tem que ser um "samurai". E isto foi feito. Acredito que a ideia foi rapidamente disseminada por que passaram-se 22 anos e hoje parece que é isto que todos entendem. Parece que houve um entendimento geral. É lógico que ainda encontramos alguns erros aqui, outros ali, mas no geral já não é mais como antes. E mais, parece que as empresas entenderam que o robô não solda melhor que o soldador ou soldadora! Solda igual, se o melhor soldador ou soldadora for aquele ou aquela que o estiver programando. Pode até melhorar, mas quem deverá programá-lo continuará sendo o melhor soldador ou soldadora. Desta forma o que sinto é que, sim, continuaremos robotizando a soldagem, é inevitável, e que isto implicará que continuaremos precisando dos melhores soldadores ou das melhores soldadoras. Por isto valorizo muito o treinamento. Por isto acho que precisamos incentivar as escolas a formarem mais técnicos e, soldadores/soldadoras. Investir em novas tecnologias também. Os programas de robôs já estão mais amigáveis. Está cada vez mais fácil programar robôs. Precisamos continuar estudando os efeitos das fontes de energia para soldagem para entender melhor os fenômenos físicos, químicos, metalúrgicos e mecânicos para facilitar cada vez 
mais o uso da soldagem. É o controle, a monitoração o entendimento e o aceite do inevitável. Daí a importância da formação de todos os níveis de pessoas na área de soldagem. Daí a importância de desenvolvermos cada vez mais pesquisa básica e aplicada de ponta para o desenvolvimento da área. Daí a importância de divulgarmos isto na Soldagem \& Inspeção para que os outros vejam.

O terceiro ponto que gostaria de, na verdade, encaminhar é o relacionado ao termo "inovação". Este termo tem sido muito utilizado nos últimos tempos, mas parece que o cerne do conceito que ele carrega atualmente não tem sido muito bem entendido. O termo "inovação" já existia desde o inicio dos tempos ou quando as línguas começaram a ser desenvolvidas ou usadas e significa criar algo novo. De acordo com o Dicionário Aurélio [4] inovação significa "ato ou efeito de inovar", "novidade" e inovar "renovar"”, "introduzir novidade em". O que se pretende com esse termo atualmente é incorporar o conceito de "novidade". Sendo assim, não precisa ser algo necessariamente novo. Desta forma, a soldagem aparece que é uma boa opção para se obter novidades. Veja por exemplo a soldagem por fricção. Já existia a muito tempo, mas somente atualmente ela tem sido a vedete dos congressos e feiras. Isto é porque ele trouxe o conceito de novidade. É o mesmo caso da manufatura aditiva. Já existia desde a década de 60. Não é novo [5]! Mas é novidade, e assim existem varias e mais opções de realizá-la hoje. Por isto ela tem sido muito cobiçada e estudada. Isto não é ruim não, é excelente. O que quero encaminhar é na verdade uma pergunta: qual será o próximo? Será que aparecerá na Soldagem \& Inspeção?

\section{Referências}

[1] Curso Intensivo de Preparação de Mão de Obra Industrial [página da internet]. Belo Horizonte: UFMG; 2018 [acesso em 23 de agosto de 2018]. Disponível em: http://www.cipmoi.eng. ufmg.br/

[2] Pacheco K. Women who weld: lighting the way out of poverty. Welding Journal. 2018;97(7),84-87.
[3] Astin K. Women welders behind the arc. Welding Journal.2018;97(7):88-91.

[4] Ferreira $A B H$. Dicionário (Aurélio) da língua portuguesa. Rio de Janeiro: Editora Nova Fronteira; 1977.

[5] Wohlers T, Gornet T. History of additive manufacturing. Fort Collins: Wohlers Associates, INC; 2014. Wohlers Report. 